\title{
Printmaking in Nigeria: Its Evolution and Developmental History
}

\section{Eyitayo Tolulope ljisakin}

\author{
Department of Fine and Applied Arts, \\ Obafemi Awolowo University, Ile-Ife, Nigeria
}

Doi: 10.2478/ajis-2019-0036

\begin{abstract}
Despite the prolific and ingenious productivity of the printmakers in Nigeria, the significance of their creative endeavours has not been given adequate attention by scholars of contemporary Nigerian arts. Scholarship on the printmakers has been limited to catalogues of art exhibitions, skimpy art reviews in magazines, and a few sketches on their biographies. This study therefore probes into the evolution of printmaking in Nigeria. This is with a view to obtaining its developmental history and enabling a more nuanced and useful understanding of the ways in which printmaking contributes to contemporary art praxis in Nigeria. Relying on field investigation, data were collected through in-depth interviews of printmakers, art critics, art historians and gallery owners, using oral or interactive formats; and collection of visual media sources. This study justifies the need for a developmental history; it identifies and examines the key actors who pioneered printmaking in Nigeria. It further appraises printmaking in Nigeria through the lens of relevant literature; and examines workshops, training, and techniques of printmaking in Nigeria.
\end{abstract}

Keywords: Printmaking, contemporary Nigerian art, Bruce Onobrakpeya, history of art, printmaking technique, visual culture

\section{Introduction}

Printmaking is an art form that produces text, pictures or illustrations on paper, fabric, parchment, metal, plastic, or any other supports, by different techniques (which include engraving, etching, woodcut, linocut, screen printing, and photo stencilling), directly by the printmaker. This particular type of prints often called "fine prints" is considered unique works of art, despite the fact that they can exist in multiples. Print has been described by scholars as an image or design made, and taken by pressure from the inked surface of a woodblock or lithographic stone, or from lines engraved or etched in a metal plate and other suitable mediums which can print hundreds of identical copies (Godfrey, 1978; Onobrakpeya, 1985; Griffiths 1996; Chilvers, 2004).

Printmaking could be traced back to the prehistoric age, while the first print to be observed by man was believed to have been his own foot-print and those of the animals he hunted. This realization might have inspired the art using different available materials. Urton's (2014) description of man's initial attempt at making prints shows that the prehistoric man practically placed his hand on the walls of caves and blew pulverized colouring substance on it, thus making a print. This explains the probable process of the print image (Plate 1) in El Castillo Cave, in Spain (National Geographic News, 2012). This process became a practice and a medium of communication long before the invention of the printing press. The prehistoric rock art employs a variety of printmaking techniques using stone tools. The prehistoric people make engravings of humans, fish, bird and other animals on bone, ivory and stone, they depicted varied subject matters such as hunting and herding. Some of the impressive pictorial records of engravings left by the prehistoric people in the 
caves and on rock surfaces include the naturalistic impression of a neighing horse (Plate 2) etched in clay (13000 -10000 BC) in the Montespian Cave, France. Another example is the Bronze Age schematised rock engraving of boats (Plate 3 ) discovered near Borge, Norway, (the Encyclopaedia Americana, 2006). The South African Paleolithic rock art is also exemplified in a coarse-pecked petroglyph of a grazing antelope (Plate 4).

Printmaking methods had long been employed in Nigeria, especially in indigenous art practices as a means to certain aesthetic ends if not as an end in itself. This is evident in wood carving, ivory carving, calabash carving, blacksmithing, Adire Eleko (starch resist dyeing techniques) and other decorative arts that share affinities with woodcut relief, intaglio, and serigraphic processes of printmaking. Howbeit, when and how did printmaking evolve in contemporary Nigerian art; and to what extent has the genre developed? What significant contribution has it also made to art praxis in Nigeria? This study therefore probes into the evolution of printmaking in Nigeria with a view to obtaining its coherent developmental history, and enabling a more nuanced and useful understanding of the ways in which printmaking contributes to contemporary art praxis in Nigeria.

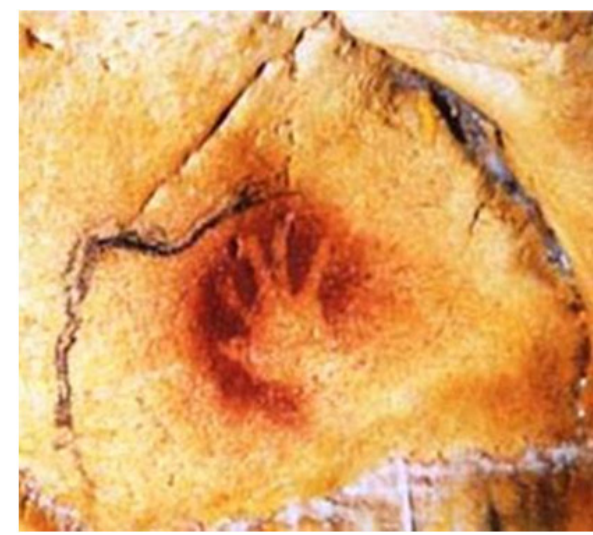

Plate 1: "Print" El Castillo Cave, Spain (28,000 BCE)

National Geographic News (2012)

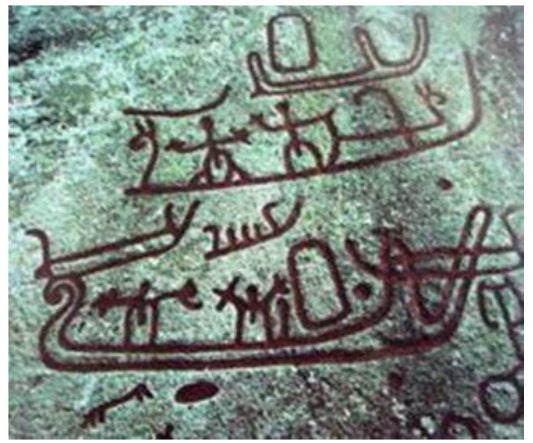

Plate 3: Bronze Age Rock Engraving of Boats, Borge, Norway. Helleristninger (Halristinger) Rock Carving http://www.arild-hauge.com/arildhauge/no-begeby-borge-estfold1.jpg

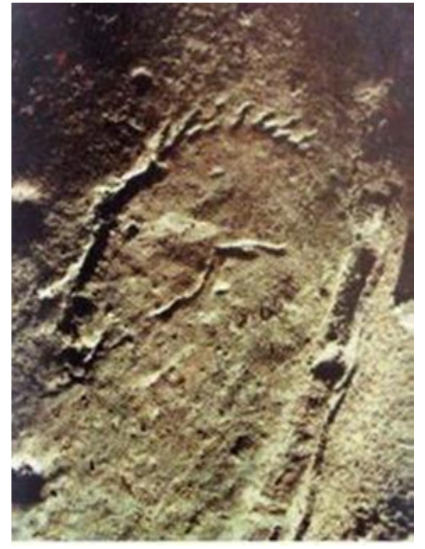

Plate 2: A neighing horse, etched in clay Montespian Cave, France

Academic American Encyclopaedia (1989)

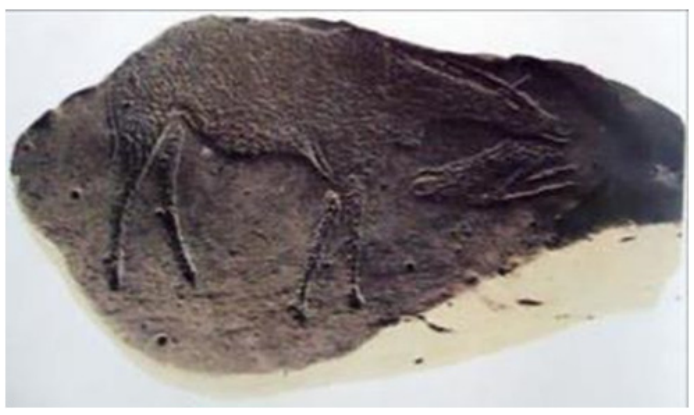

Plate 4: A grazing antelope South African Paleolithic Rock Art Academic American Encyclopaedia (1989). 


\section{The Rationale for a Developmental History of Printmaking in Nigeria}

Studies of notable scholars such as Hind (1923), Hayter (1962), Woods (1965) and Godfrey (1978) laid the foundation for scholarship on printmaking; while others have also conducted studies on the history, techniques, processes, and other aspects of printmaking (Walker 2010, Riley 2012, Stijnman 2012). Although these studies are useful contributions to scholarship; however, while writing from their own cultural contexts, printmaking artists from Africa were simply out of their scope. Hence, most of them follow the point of view that grounded contemporary printmaking in Europe and the Asia.

Moreover, since studies on Nigerian arts started over a century ago, intellectual discourse has often tended towards sculpture and painting traditions, while very little could be found in the literature about printmaking. This however is not peculiar to Nigeria as Griffiths (1996) affirms that many of the works by some of the world's greatest artists are prints ${ }^{1}$, yet little is known about this genre of art. Moreover, the bulk of available literature on Nigerian art focused mainly on traditional art forms (Gillion, 1984; Willet, 2002; Abiodun et al, 1994; Adepegba, 1995; Blier, 1998; Visona et al, 2001; Drewal and Schildkrout, 2009; and Silvester, 2009). Most of the literature on contemporary art concentrates more on the artists, techniques and processes in painting, sculpture and other art forms (Fosu, 1986; Kennedy, 1992; Oloidi, 1993; Kasfir, 1999; Enwezor and Okeke-Agulu, 2009; Onobrakpeya, 2009; Oyelola, 2010; and Castellote, 2012).

Despite the fact that Nigeria is endowed with many artists who work in the printmaking medium, only Bruce Onobrakpeya, a self-documented printmaker could be said to be well published (Onobrakpeya 1985, 1989, 1999a, 1999b, 2003, and 2009). These publications however, are more or less autobiographies which only open the subject for further discussion. The paucity of research on printmaking in contemporary Nigerian art therefore calls for concern. For instance, the Hour Glass Gallery (2014) highlights the pioneering efforts of Aina Onabolu towards entrenching art in the school curriculum. It traces the chronological memoir of contemporary Nigerian art using master artists such as Erhabor Emokpae, Okpu Eze, Bruce Onobrakpeya, Uche Okeke, Abayomi Barber, Solomon Irein Wangboje, Ben Osawe, Bisi Fakeye, Lamidi Olonade Fakeye, and Kolade Oshinowo. It also identifies major art schools such as the Ife art school, Zaria, Nsukka and Yaba schools of art; as well as the Mbari Mbayo Osogbo art workshop experiment. However, the study did not make any significant reference to printmaking as a medium of expression by Nigerian artists, neither was printmaking mentioned as a field of study in any of the schools of art. Based on the foregoing, it can be concluded that literature with specific focus on the evolution and developmental history of printmaking in Nigeria is scarce. This study is significant to intellectual discourse as it provides information on the evolution and development of printmaking in contemporary Nigerian art.

\section{Methodology}

Data for this study depends significantly on field investigation. In-depth interviews were conducted on printmakers, art critics, art historians and gallery owners, using oral/interactive format. The Harmattan Workshop in Nigeria offered the opportunity to interview many of the key informants; others were interviewed in their private studios. Field notes and photographs of artists and their works were also taken. Secondary data were collected from catalogues of art exhibitions, textbooks, journal publications, and Internet sources. Data collected were analyzed using the descriptive approach of art historical study.

\footnotetext{
${ }^{1}$ Some prints of the world's greatest artists have been identified by Saff and Sacilotto (1978). These include the Temptation of Saint Anthony (1480-1490); and, Death of the Virgin (1470-1475) by Martin Schongauer. Christ Bearing the Cross (1498-1499); the Last Supper (1510); Knight, Death and the Devil (1513); Saint Jerome in His Study (1514); and, the Beautiful Virgin of Ratisbon (1519) by Albrecht Dürer. Others are Lucas Van Leyden's Jezebel and Ahab (1517-1518); Rembrandt Harmenszoon van Rijn's Death of the Virgin (1639); Henri De Toulose-Lautrec's the Seated Clowness from Elles (1896); as well as Pablo Picasso's Bust of a Woman after Cranach the Younger (1958).
} 


\section{Printmaking in Nigeria: A Review of Literature}

In tracing the history of printmaking in Nigeria, Filani (2004) opines that all human communities in ancient times manifest printmaking exercises in one way or the other. Traditional Nigerian crafts of calabash carving, wood carving, and blacksmithing among others that require careful cutting and incising are known to share techniques of printmaking such as relief and intaglio. The study observes that indigenous Yoruba art of Adire Eleko (starch resist dyeing techniques) employs serigraphic methods of printmaking. It is therefore reasonable to conclude that printmaking techniques have been practiced by traditional artists in Nigeria.

A few studies have also examined the works of printmakers in contemporary Nigerian art. For instance, Onyeanu (2002) expatiates on the contributions of Solomon Ona Irein Wangboje, Bruce Onobrakpeya, Uche Okeke, Vincent Chuks Amaefunah, Obiora Udechukwu, and Paul Igboanugo to the development of printmaking. The study further highlights high cost of printmaking materials, lack of capital and state of the art equipment as parts of the challenges confronting effective development of printmaking in Nigeria. On the other hand, Nnadozie (2006) offers a critique of the works and contributions of Paul Igboanugo as a printmaker. Though limited to only a few printmaking artists the studies of Onyeanu and Nnadozie are relevant in identifying some of the printmaking artists and their contributions to contemporary Nigerian art.

Solomon Wangboje is considered as one of the foremost printmakers in contemporary Nigerian art (Smithsonian National Museum of African Art, 2014). Creative exploration in the possibilities of printmaking as a medium is fundamental to Wangboje's works. His interest in printmaking may not be unconnected with the technical processes of the medium; more so, that "the Zaria school of his time stressed the striving for technical mastery of medium and process over and above any profound inquiry into questions of artistic identity and formal style" (Okeke-Agulu, 2012). A critical analysis of Wangboje's printmaking oeuvres reveals prolific usage of African cultural tradition and daily life of the Nigerian people as his subject matter. He uses geometric shapes in an overlapping manner that resonate the traditional African sculpture; his works are also noted for extraordinary depth, rich colours and bold lines (Ijisakin 2016).

The art of Onobrakpeya has been described as a poetic projection as he was always on the search for new ways of expression, most importantly the development of a bronze-lino technique of printmaking and its subsequent results (Lawal 1976). Jegede (1982) emphasizes the syncretistic tendency in Onobrakpeya's art; noting how he synthesizes Urhobo and Yoruba motifs to create a new art form. Jegede (1987) further describes Onobrakpeya as a master printmaker, a title acquired through the international acceptance and recognition of his prints. In discussing the tradition and modern tendencies of Nigerian Art, Adepegba (1995) further confirms Onobrakpeya's popularity as a printmaker; while the analysis of his prints in terms of subject matter, forms and sources of inspiration is provided by Oyelola (2003). Onobrakpeya wields positive and practical influence on the development of printmaking in contemporary Nigerian art. The new artistic forms, styles and inventions achieved in the course of Onobrakpeya's numerous experimentations had influenced younger generation of artists more than any other person in contemporary Nigerian art scene. Onobrakpeya is the most published artist in the history of Nigerian art; he has authored several books to document his oeuvres (ljisakin 2016) ${ }^{2}$.

Onakufe (1999) evaluates Plasto-Viscosity as a method of printmaking, Onakufe's study brings to the fore how to achieve the effects of colour, light texture, and rhythm in painting through the juxtaposition of colour using roller on relief plate. The problems and prospects of the method are highlighted; and if properly explored will lead to exciting visual aesthetic perception. Elebute (2006) examines the trends in Nigerian deep-etchings (a major technique of printmaking) with emphasis on the characteristics of the printmakers' works, especially their themes, techniques, styles, forms, and the use of colour, with reference to similarities and differences. The study examines four different techniques that can be used for deep etching which include: Plastography,

${ }^{2}$ Bruce Onobrakpeya has also been mentioned copiously by many authors and scholars of African art. See Kennedy, 1992; Nzegwu, 1999; Picton, 1997, and 2004; Foss, 2004; Oyelola, 2010. 
Thermoplastography, Additive Plastography, and Collagraphy. The study is however limited to the works of Bruce Onobrakpeya, David Dale, Rukeme Noserime, Nse-Abasi Inyang, Tayo Quaye, John Onobrakpeya, Joe Amenechi, Tunde Ogunlaiye, Kunle Adeyemi, Ufuoma Onobrakpeya, Abiodun Okemakinde, Jude Ifesiah as well as Raymond Onodje. Ijisakin et al (2019) identify diverse techniques of printmaking and examine how the printmakers in Nigeria have employed both conventional and innovative techniques to create unique works of art.

By and large, previous studies have considered some aspects of printmaking in Nigeria; however, much of these studies have concentrated on the personalities of one or a few printmakers, thus leaving out details on the evolution and development of the genre. Furthermore, of all the printmakers in contemporary Nigerian art only Bruce Onobrakpeya has made several attempts to document his works. These documentations however, are more or less autobiographical surveys. Hence, it becomes highly imperative to obtain a lucid and wellresearched historical account on the evolution and development of printmaking in Nigeria.

\section{Evolution and Development of Printmaking in Nigeria}

In contemporary Nigerian art, printmaking became apparent when Rudolf Harold "van" Rossem, a Dutch printmaker demonstrated some printmaking techniques to students at the Nigerian College of Arts, Science, and Technology ${ }^{3}$ (NCAST), Zaria, in1958. Notable attendees among the NCAST students where relief printmaking methods had been introduced include Bruce Onobrakpeya and Solomon Irein Wangboje (Filani 2004). Rossem also demonstrated some printmaking techniques (Plate 5) at the Mbari Mbayo Artists and Writers' Club, at Ibadan in 1961; and at the Mbari Mbayo art workshops, Osogbo in 1962 and $1964^{4}$. These workshops were initiated by Ulli Beier and led by Julian Beinart, Amancia Guedes, and Ru Van Rossem (Stanley, 2011). The participants at the workshops include Bruce Onobrakpeya, Muraina Oyelami, Taiwo Olaniyi (Twins Seven Seven), Nike Davies Okundaye, Adebisi Fabunmi, Tijani Mayakiri, Ademola Onibonokuta, Jimoh Akolo, Asiru Olatunde, and Adebisi Akanji. Jimoh Buraimoh, Rufus Ogundele, and Jacob Afolabi are other participants whose works are presented in Plates 6, 7, and 8 respectively.

Since Rossem's demonstrations, printmaking has been evolving with tremendous landmark achievements such that Sheba (2004) claims that printmaking enjoys a considerable influence among the contemporary Nigerian artists who engage in its production as an aesthetic means of expression. Sheba further argues that the printmakers are not technically fixated as they often experiment and invent several techniques of their own, using series of improved materials to produce their prints as they are immersed in an ecstasy of creative urges.

Having been deeply impressed by the successes of the Mbari art workshops in Ibadan and Osogbo, Solomon Wangboje facilitated the printmaking workshop of the Ori Olokun Cultural Centre at Ile-Ife. According to Crowder (1970), the Ori Olokun Cultural Centre of the Institute of African Studies, University of Ife (now Obafemi Awolowo University), Ile-Ife, was established in June 1968 with a view to synthesizing traditional art and culture as well as bridging the gap between the traditional and Western trained artists. In other to forge a link with the pioneer work of the Mbari art workshops, Wangboje invited Rudolf Harold "van" Rossem and Bruce Onobrakpeya; as well as other prominent members of the Mbari Mbayo art workshop from Osogbo such as Rufus Ogundele, Muraina Oyelami, Jimoh Buraimoh, Tijani Mayakiri, and Adebisi Fabunmi. They were to serve as instructors/facilitators, and to help in nurturing the nascent Ori Olokun workshop into a flourishing centre.

The participants at the Ori Olokun Cultural Centre were allowed freedom to creatively express themselves. They were also encouraged to explore their indigenous cultural background for

\footnotetext{
${ }^{3}$ The Nigerian College of Arts, Science, and Technology, Zaria, is the first formal art institution in Nigeria which later became Ahmadu Bello University.

${ }^{4}$ Bruce Onobrakpeya, interview with the author, March 7-10, 2013, Harmattan Workshop, Niger Delta Cultural Centre, Agbarha-Otor, Nigeria; and, Kunle Filani, interview with the author, September 3, 2015, Federal College of Education (Technical), Akoka, Lagos.
} 
inspiration in which they used to create fresh and unique works of art. The printmaking artists that emerged from the Ori Olokun art workshop include Ademola Williams, Yinka Adeyemi, Adeniji Adeyemi, James Adedayo, Kola Sorunke, Gbade Akintunde, Fela Odaranile, Bayo Ogundele, Wale Olajide, Raifu Oladepo (also known as Mr. Kala), and Segun Adeku ${ }^{5}$. Ori Olokun art workshop flourished until 1972 when Wangboje left lle-lfe for Ahmadu Bello University, in Zaria. Later, the Ogun Timehin Studio was set up by Rufus Ogundele in 1974. With the foregoing, the seed of printmaking is sown, and has since been flourishing in contemporary Nigerian art. Two hundred and twenty (220) printmakers have been identified in contemporary Nigerian art, the printmakers are classified as pioneer, academic-trained, and workshop-trained artists (ljisakin 2016).

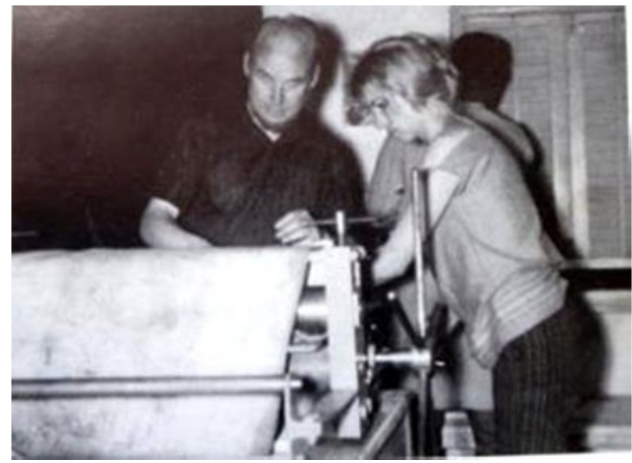

Plate 5: Ru Van Rossem with Georgina Beier, Printing an Etching, Osogbo 1963

Ulli Beier (1991): Thirty Years of Osogbo Art

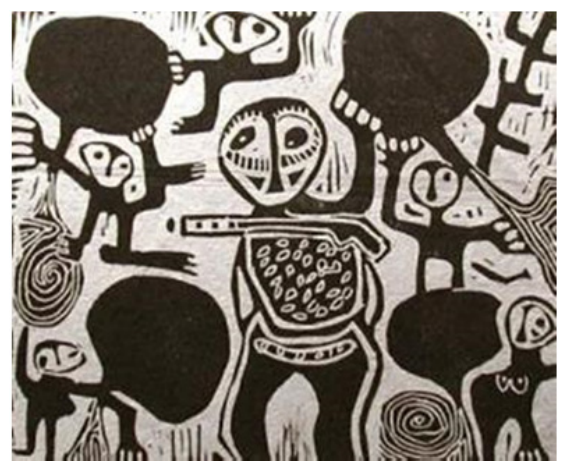

Plate 7: Oluode in the Forest

Linocut; Rufus Ogundele (1960s)

http://www.africancraft.com/artist.

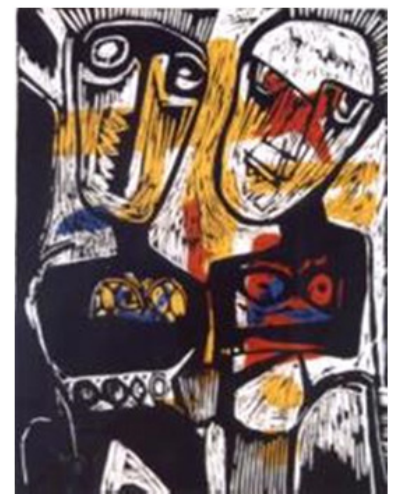

Plate 6: The Couple Jimoh Adetunji Buraimoh http://www.buraimoh.com/artsmore.htm

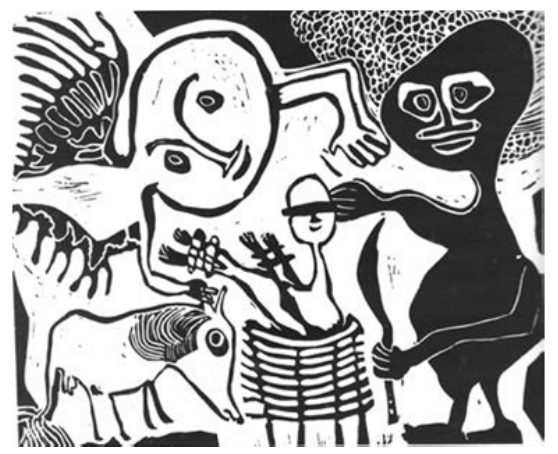

Plate 8: Abraham's Sacrifice

Linocut; Jacob Afolabi (1963)

Ulli Beier (1991): Thirty Years of Osogbo Art

\subsection{The pioneers of Printmaking}

Those at the vanguard of propagating printmaking in Nigeria include Solomon Irein Wangboje, Bruce Onobrakpeya, and David Hebert Dale. Wangboje was a pioneer graduate of the School of

${ }^{5}$ Segun Adeku, in a personal interview with the author (February 12, 2016, Olokun Art Gallery, Ile-Ife, Nigeria), claims that although he benefited immensely from the Ori Olokun Art Workshop, he was however not an official participant at the workshop. 
Arts, Science, and Technology, Zaria; he also bagged a Master of Fine Arts (MFA) degree in Printmaking. Wangboje contributed to the inclusion of printmaking in the curriculum of the University of Benin in the late 1970s. Wangboje did not dwell on the academic zone only, but also combines the theory with practice of art, as well as administrative prowess successfully; his many exhibitions at home and abroad exemplify his contributions to the dawning of the glory found in printmaking as an art medium in Nigeria (Filani 2015) ${ }^{6}$.

Oladumiye (2006) described Wangboje as an exponent of varied media in printmaking whose strength lies in superimposed background; and that the Ori-Olokun Art Workshop in the University of Ife (now Obafemi Awolowo University) is one of Wangboje's contributions to the development of printmaking as a specific genre in Nigerian art scene. "Wangboje gradually drove the vehicle of printmaking to the political arena, picking passengers along without collecting fares" (Ojo 2000). This is in recognition of Wangboje's immense contribution towards the art of printmaking as a studio activity that compares favourably with painting and other major branches of Fine and Applied Arts. Oyelola (1976) asserts that under Wangboje's guidance, artists such as Ademola Williams and Rufus Orishayomi evolved out of Ori-Olokun art workshop. They are said to have created prints in a bold, simplified style of social activities in Nigeria, and that striking images derived from natural phenomena were also created.

The development of Onobrakpeya as a printmaking artist could be traced to his experience at the Western Boys High School, Benin City; and Ondo Boys High School, Ondo; as well as the Nigerian College of Arts, Science, and Technology, Zaria. Onobrakpeya, a leading exponent of printmaking is famous for his deep etching technique. The technique evolved as a result of an accidental occurrence at a print workshop in 1963 when hydrochloric acid damaged one of the plates he was working on. To repair the plate, he filled it with araldite and ingeniously produced a print from it. Onobrakpeya observed that the print came up with stimulating sculptural attributes; this marked the evolution of Onobrakpeya's deep etching.

Experimentations and innovations are central to Onobrakpeya's oeuvres as a printmaking artist, his subject matter include day to day life activities of the peasants, environmental influences, religious and mythological ideas, traditional African philosophy, especially the myths and legends of his Urhobo people. Onobrakpeya's works (Plates 9 and 10) reveal the instinctive clarity and the deep-rooted obsession for the art of printmaking. Lawrence (1979) argues that:

Clearly Onobrakpeya has made some distinctive additions to contemporary art through his technical facility. Yet, he is no mere technician. What has emerged from the etching processes he perfected in the latter 1960's is a flexible medium which has kept pace with the increasing complexity of his own imaginative demands.

In the observation of Picton (2004), Bruce Onobrakpeya is among the renowned artists with significant records of achievements in the twentieth century West Africa, he also has a great influence on the generation of artists in the postcolonial Nigeria. Corroborating this assertion, Elebute (2005) argues that stylistic development of deep etching technique of printmaking is traced to Bruce Onobrakpeya, who also has a massive influence on other printmakers.

David Dale is a foremost Nigerian artist and a graduate of Fine Arts from Ahmadu Bello University, Zaria. Dale is known for his versatility in over twenty-three different media which include deep-etching (Plates11), engraving, beadwork, plastocast ${ }^{7}$, as well as metal foil casting, all which attest to the pleasantly delicate and elegant characteristics that have distinguished his works. Dale

\footnotetext{
${ }_{7}^{6}$ Kunle Filani, interview with the author, September 3, 2015, Federal College of Education (Technical), Akoka, Lagos.

${ }^{7}$ Plastocast: is a technique of printmaking in which drawing is made on Plaster of Paris (POP); the drawing is then engraved into the POP to serve as a negative mould. Lacquer is used to seal up the holes in the POP, clear oil or neutral polish is applied to cover the whole surface of the engraved POP to serve as a separator for the resin or araldite that is poured unto the engraved POP to take the mould. This positive mould becomes the master plate from which many identical and original copies is made by putting metal foil on top of it; pressure may be exerted manually but preferably through an etching press. This technique which was invented by Bruce Onobrakpeya is so called Plastocast, because the resin or araldite used to cast the mould is a plastic medium. Hence, the name "Plastocast" is a derivative of plastic and cast.
} 
participated in the Ori-Olokun Cultural Centre art workshop of 1973 in Ile-Ife, and also produced many graphical illustrations using printmaking techniques with linoleum and araldite. According to Oyelola (1976), Dale is an exponent of the printmaking technique of deep etching, he chooses his subjects from rural life and landscape, and expresses his flairs for rich and dramatic colours. Filani (1989) and Oloidi (1993) see David Dale as a symbol of hard-work and commitment, an artist that is not restricted to a particular style; and with zeal and overwhelming love for the expression of printmaking. Dale has followership among many developing printmakers who are taught the intricacies of his printmaking techniques. While analysing the forms in the printmaking of David Dale, Elebute (1997) asserts that the landmark of Dale's etching lies in its simplicity, directness and perfect unison between the subject-matter and the medium.

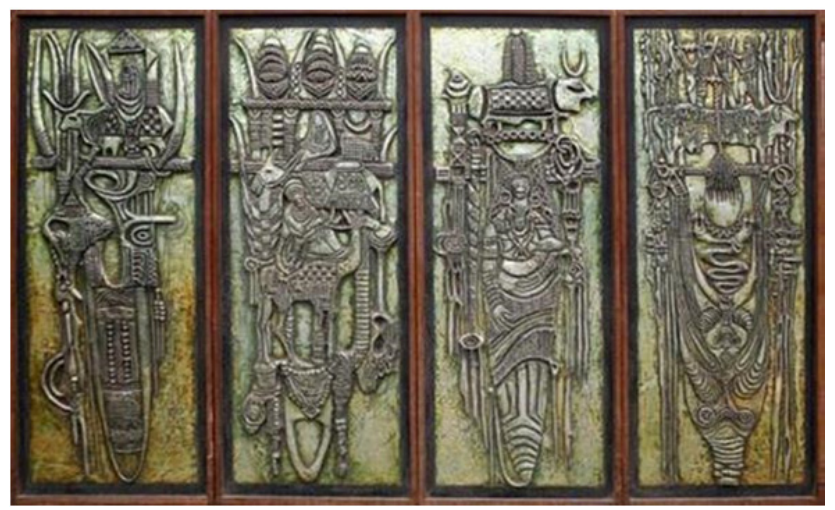

Plate 10: Hail New Moon II (Emeranvwe Phru-Go-o)

Plastograph; Bruce Onobrakpeya (1988)

Photograph by Eyitayo ljisakin

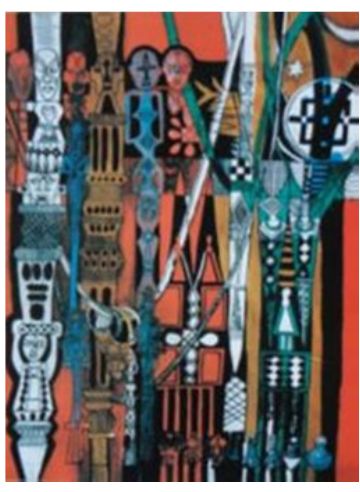

Plate 9: Sahelian Masquerade Deep Etching

Bruce Onobrakpeya (1988)

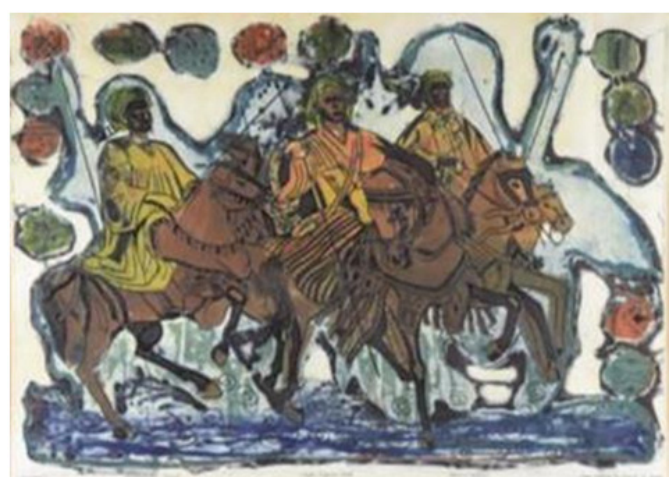

Plate 11: Durbar; Deep Etching; David Herbert Dale (1979) http://www.mutualart.com/Artwork/Durbar /6673E37D1898DE5A/

\subsection{Training of the printmakers in Nigeria}

Some of the workshop centres that have served as training grounds for printmakers in Nigeria include the Mbari Writers' and Artists' Club, Ibadan (1962); and, the Mbari Mbayo in Osogbo in the 1960s. The Ori Olokun art workshop at Ile-Ife later came in the 1970s; this was followed by the Ogun Timehin Studio, also in Ile-Ife. Though these workshops have ceased to exist, their contributions to the development of printmaking in Nigeria cannot be overemphasized. For 
instance, it was the experiences that Onobrakpeya garnered at these workshops that afforded him the understanding that informal interaction between experienced and aspiring artists could yield so much positive results through creative experimentation; he also got the conviction that artistic experiments that are initially not successful can still unlock new doors of possibilities in creativity ${ }^{8}$. These accumulated experiences inspired Onobrakpeya so much that he started ruminating on how to positively impact the society with his own kind of art workshop.

Onobrakpeya eventually established the Harmattan Workshop in 1998 as a fulfillment of a dream nurtured for a period of over twenty years. The location of the workshop in Agbarha-Otor, hometown of Onobrakpeya, is to help him get closer to the sources of inspiration for many of his art works; moreover, Agbarha-Otor is culturally known as a repertoire of folklore, traditional art and philosophy from which artists can draw inspiration (Onobrakpeya, 1999b). The name "Harmattan" is given to the workshop because it usually holds during the Harmattan period of the year between December and March. Printmaking features prominently in the series of Harmattan Workshop which has been holding annually since its inception in 1998. It is usually anchored by Bruce Onobrakpeya with the supports of other distinguished printmakers. Some of the participants at the printmaking section of the workshop are Eyitayo ljisakin, Ezekiel Adebayo, Biodun Agbelusi, Luqman Alao, Patrick Akpojotor, Barret Akpokabayen, Aderinsoye Aladegbohungbe, Stella Awoh, Sweet Eboigbe, Lanre Ayoade, Ayo Elebute, Charles Ohuabunwa, Ogbemi Heymann, Nse-Abasi Inyang, Abiodun Okemakinde, Olaniyi Ojo, Oyedele Oluseye, as well as Akaninyene John Sampson. With the Harmattan Workshop, Onobrakpeya has clearly expressed his penchants for informal egalitarian art workshop where people who wish to practice art, but lack the necessary academic qualifications for formal education have the opportunity to acquire some skills that could propel them into their artistic career (Onobrakpeya, 1999b). Onobrakpeya enjoins participants at the workshop never to worry about producing a master piece within the very short period of the workshop. However, they are to be open-minded and creative in their search for treating an idea in different ways to achieve optimum innovative results.

Apart from these art workshops, some private art studios are also involved in training of artists and art enthusiasts in the processes and techniques of printmaking. These include Solomon Wangboje's Creative Arts Centre at Owoseeni Street in Benin City; Bruce Onobrakpeya's Ovuomaroro Gallery and Studio at No. 4, Oloje Street, Papa Ajao, Mushin, Lagos; Kunle Adeyemi Studios at No. 48, Oduduwa Street, Mushin Olorunsogo, Lagos; Juliet Ezenwa Maja-Pearce's Yemaja Studio and Art Gallery, Lagos State; Universal Studios of Art, National Theatre, Iganmu, Lagos; Jimoh Buraimoh's African Heritage Art Gallery, No. 1, Jimoh Buraimoh Street, Odi-Olowo, Osogbo; as well as Segun Adeku's Olokun Art Studio, lle-Ife. In all the aforementioned studios, apprentices are enrolled from time to time; moreover, students from academic institutions of higher learning often observe their mandatory Students Industrial Work Experience Scheme (SIWES) at the studios as Industrial attaché.

Aside the informal training of printmaking artists at the workshop centres and private studios, the academic institutions in Nigeria also offer training programmes in their Departments of Fine and Applied Arts across the country. These include the Ahmadu Bello University (ABU), Zaria; the University of Nigeria, Nsukka; Obafemi Awolowo University, Ile-Ife; the Federal University of Technology, Akure; University of Lagos; Olabisi Onabanjo University, Ibogun Campus; University of Port Harcourt; Niger Delta University; University of Uyo; Cross River State University of Technology; Nnamdi Azikwe University, Awka; University of Maiduguri, Ladoke Akintola University of Technology, Ogbomoso; and the University of Benin (UNIBEN), Benin City. The UNIBEN encourages the postgraduate students on Master of Fine Arts (MFA) Degree in Printmaking, and other art students to participate in the Harmattan Workshop as part of their regular training programme; while Delta State University, Abraka, offer $\mathrm{PhD}$ in Visual Arts with provision for printmaking as a major field of specialization.

In addition, Yaba College of Technology, Yaba; Institute of Management and Technology (IMT),

${ }^{8}$ Bruce Onobrakpeya, interview with the author, March 7-10, 2013, Harmattan Workshop, Niger Delta Cultural Centre, Agbarha-Otor, Nigeria. 
Enugu; the Polytechnic Ibadan, Lagos State Polytechnic (Laspotech); Federal Polytechnic, Auchi; are among other tertiary institutions where some aspects of printmaking are taught. Some of the printmakers that emerged from the formal academic institutions include Obiora Udechukwu, Ogbonnaya Nwagbara, Eyitayo Tolulope ljisakin, Kunle Adeyemi, and Juliet Ezenwa Maja-Pearce; their works are presented in Plates 12 through to 17 respectively. Others are Christopher Uchefuna Okeke, Yusuf Grillo, Eben Sheba, Kunle Filani, Lade Adeyanju, Funmilayo Oluwadiya, Francis Arodu, Chuka Vincent Amaefunah, Dele Oluseye, Dupe Abejide, Feyisara Omolola, and Nse-Abasi Inyang.

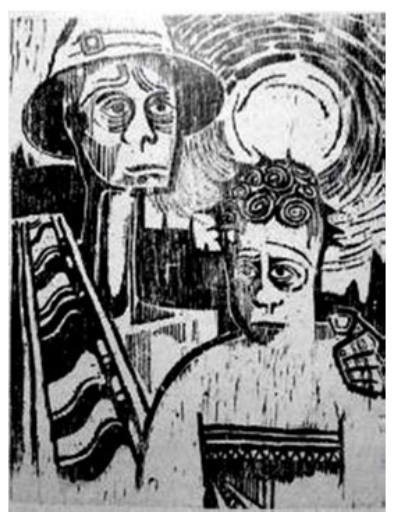

Plate 12: The Exiles (Facing the Unknown); Woodcut Obiora Udechukwu, (1973)

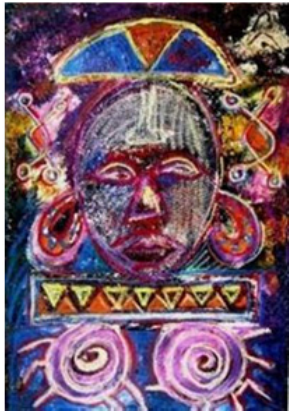

Plate 14: African Bride

Additive Collagraph

Eyitayo Tolulope ljisakin (2007)

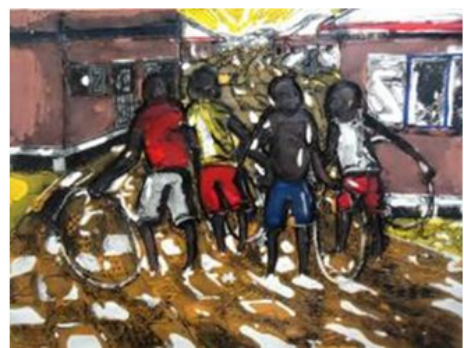

Plate 16: Childhood Reminiscence Deep Etching and Serigraphy Kunle Adeyemi (2013)

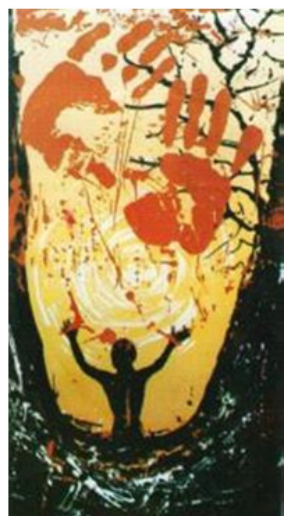

Plate 13: Akalaka (Destiny); Serigraph Ogbonnaya Nwagbara (1961)

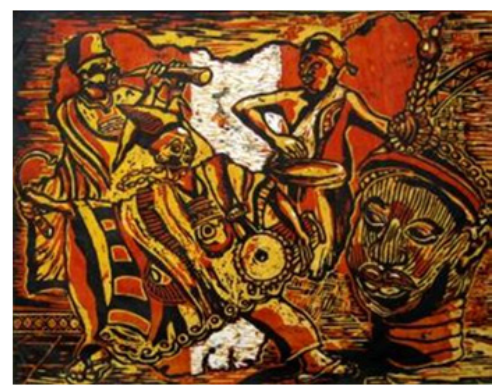

Plate 15: Art and Culture: the Nigerian Heritage

Linocut; Eyitayo Tolulope ljisakin (1998)

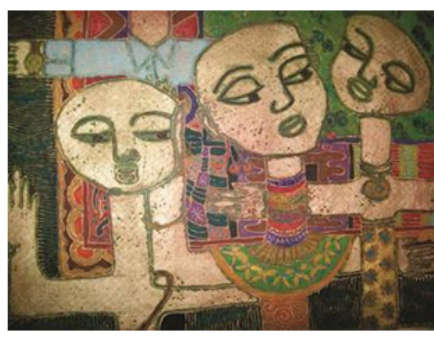

Plate 17: Family 55 x $78 \mathrm{Cm}$.

Additive Plastograph;

Juliet Ezenwa Maja-Pearce (2010) 


\subsection{Techniques of the printmakers in Nigeria}

Some of the techniques of printmaking ${ }^{9}$ that have been used by printmakers in Nigeria to produce enthralling works of art include the conventional Relief, Intaglio, and Planographic methods. They also employed innovative techniques that are uniquely Nigerian; these innovative techniques evolved out of a series of creative experimentation. In Relief techniques of printmaking, it is from the raised part of the surfaces that the printing is made. Some of the Relief techniques include wood cut, wood engraving, as well as Lino cut. A bold conception of design, expressed more in areas than in lines is a unique characteristic of the Relief techniques.

Intaglio is the opposite of the relief technique, and includes all forms of engraving on metal. Copper plates are traditionally used, although zinc, steel, aluminium and Plexiglas can also be used as printing plates. The deeper the lines are cut onto the surface, the darker and thicker the lines that would print. The method of printing is what distinguishes Intaglio from other techniques of printmaking. As the name implies, the image is cut-in, below the surface, or incised into a metal plate with various engraving tools; the image can also be etched with acids. Varied examples of the Intaglio technique include Line or copper Engraving, Etching, Drypoint, and other related processes.

In the Planographic or Surface method of printmaking, both the positive and negative areas of the designs are on the same plane. The designs are not raised as obtainable in relief, neither are they incised as it is done in Intaglio. In planographic techniques, the original surface of the matrix is specially treated to transfer the image. Typical of the planographic techniques are Lithography and Serigraphy; unlimited number of prints that the techniques offer is one of its greatest advantages. Other variants of printmaking techniques which cannot be strictly categorized as Relief, Intaglio, or Planographic include Collagraphy, Monotype, and Marbling.

The innovative techniques are Bronzed Lino Relief, Plastograph, Additive plastograph, Metal foil deep etching, and metal foil relief print, invented by Bruce Onobrakpeya. Emulsive invented by Eyitayo ljisakin, Collacan by Bode Olaniran, while the Paintograph and Paintocast technique by Kunle Adeyemi has also integrated the potentials of easel painting and printmaking to develop a new method of creative expression. Further, Filani (2004) asserts that printmaking techniques of Evolay by Francis Arodu, Starchoset by Amaefuna, and Petropolystren by Kunle Filani emerged from the academic experiments of the University of Benin in the early 1980s. The innovative techniques constitute a significant "contribution of printmaking to contemporary Nigerian art, and to the global art repertoire as a whole" (Ijisakin et al, 2019).

\section{Conclusion}

Printmaking as a medium of artistic expression became popular in Nigeria as a result of the pioneering efforts in the series of art workshops at Ibadan and Osogbo; as well as the Ori Olokun, in lle-Ife. The printmaking workshops have great positive and practical impacts on the development of contemporary art in Nigeria by creating a platform for artists from diverse backgrounds to inspire one another towards production of outstanding works of art. This is achieved through thought-provoking interactions and growth in ideas as participants are introduced to new techniques and latest materials. The printmaking workshops also empower participants in skill acquisition and cultural consciousness.

In addition, the lofty contributions of the icons of printmaking in Nigeria such as Solomon Wangboje and Bruce Onobrakpeya in their quest to propagate printmaking as a medium of artistic expression cannot be overemphasized. The variety of processes that the medium offers, coupled with its ability for creative experimentation with resultant effects in a distinct form of classical impressions that appeal to the aesthetic sense of the art enthusiasts, has also helped a lot of new and talented artists to discover their métiers in printmaking. The creative exploration of the printmakers has also extended the frontiers of knowledge in terms of novel techniques that are uniquely Nigerian. The evolution and development of printmaking in Nigeria is a significant contribution to contemporary Nigerian art history, and the entire body of artistic works worldwide.

\footnotetext{
${ }^{9}$ ljisakin et al (2019) offer a more comprehensive study on techniques of printmaking in Nigeria.
} 


\section{Acknowledgement}

The author is grateful to the American Council of Learned Society (ACLS), New York, for Dissertation and Postdoctoral Fellowships in which this research has benefited. The study has also benefited from the NRF/DST Postdoctoral Fellowship under Prof. Ruth Simbao, SARChl Chair in Geopolitics and the Arts of Africa, as well as the entire Arts of Africa and the Global Souths Research Team, Rhodes University, South Africa.

\section{References}

Abiodun, R., Drewal, H. J., and Pemberton III, J. (1994): The Yoruba Artist: New Theoretical Perspectives on African Arts. Washington and London: Smithsonia Institution Press.

Adepegba C. O. (1995): Nigerian Art: Its Traditions and Modern Tendencies, Ibadan: Jodad Publishers. Blier, S. P. (1998): The Royal Arts Of Africa: The Majesty Of Form. New York: Harry N. Abrams, Inc., Publishers,

Castellote, J. (2012): Contemporary Nigerian art in Lagos Private Collections: New Trees In an Old Forest". Ibadan: Bookcraft. p.14

Chilvers, I. (2004): The Oxford Dictionary of Art, Oxford: Oxford University Press, p. 566

Crowder, M. (1970): "The Ori Olokun Artists", in Crowder, M. (ed.) Third Ife Festival of the Arts. Ile-Ife: Institute of African Studies, University of Ife, p.18.

Drewal, H. J. and Schildkrout, E. (2009): Dynasty and Divinity: Ife Art in Ancient Nigeria. New York: Museum for African Art.

Elebute, A. E. (1997): "Pastime in Riverine Village", Mid-Week Concord, March 5, 1997:C1.

Elebute, A. E. (2005): "Stylistic Development of Deep Etching Techniques and Some Other Contemporary Nigerian Art Forms" in Bruce Onobrakpeya, Agbarha-Otor 2005, 7th Harmattan Workshop. Lagos: Bruce Onobrakpeya Foundation. Pp. 10-22.

Elebute, A. E. (2006): "Trends in Nigerian Deep-Etching: A Study of Similarities and Stylistic Variances", in Aremu, P. S. O., Ademuleya, B. A., Sheba, E. A., Adejumo, E. A, and Ajiboye, O. J. (Eds.), Contemporary Issues in Nigerian Art: Its History and Education. A referred proceeding of the International Conference on Contemporary Nigerian Arts in commemoration of the 30th Anniversary of the Ife Art School, held in the Department of Fine Arts, Obafemi Awolowo University, Ile-Ife. Pp. 69-82.

Encyclopaedia Americana (2006): Prehistoric Art; Danbury, Connecticut: Scholastic Library Publishing, Vol. 22, pp542-545.

Enwezor, O. and Okeke-Agulu, C. (2009): Contemporary African Art since 1980. Richmond: Damiani Publishers.

Filani, K. (1989): "Contemporary Printmaking in Nigeria: its Growth and Glory", in Moyo Okediji (Ed.), Kurio Africana: Journal of Art and Criticism, Vol. 1, No. 2. Ile-Ife: Department of Fine Arts, Obafemi Awolowo Univeristy. $\mathrm{Pp}, 25-41$.

Filani, K. (2004): "Brief History of Printmaking in Nigeria" in Just Prints, catalogue of the first annual printmakers' exhibition, Ikoyi, Lagos: Mydrim Gallery, pp.8-9.

Foss, P. (2004): Where Gods and Mortals Meet: Continuity and Renewal in UrhoboArt; New York: Museum for African Art.

Fosu, K. (1986): 20th Century Art of Africa. Zaria: Gaskiya Coporation Limited.

Gillion, W. (1984): A Short History of African Art. London: Penguin Books.

Godfrey, R. T. (1978): Printmaking in Britain: a general history from its beginnings to the present day, Oxford: Phaidon Press Limited, p. 9.

Griffiths, A. (1996): Prints and Printmaking: an Introduction to the History and Techniques (Second edition), University of California Press.

Hayter, S. W. (1962): About Prints. London: Oxford University Press.

Hind, A. M. (1923): A History of Engraving and Etching from the $15^{\text {th }}$ Century to the year 1914, Boston: Houghton Mifflin Co.

Hour Glass Gallery (2014): A Journey through Nigerian Art Part 1. http://www.hourglassgallery.com/web_pages/publications.html. Retrieved on Friday, January 31, 2014

ljisakin, Eyitayo Tolulope (2016): Printmaking in Contemporary Nigerian Art. PhD Thesis of the Department of Fine and Applied Arts, Obafemi Awolowo University, Ile-Ife, Nigeria.

ljisakin, Eyitayo Tolulope, Babasehinde Augustine Ademuleya, and Olusegun Jide Ajiboye (2019). "The Making of Prints: Forms and Techniques of Printmaking in Nigeria". Arts and Design Studies Vol. 71, Journal of the International Institute for Science, Technology and Education (IISTE), New York. pp.39-50

Jegede, D. (1982): Trends in Contemporary Nigerian Art: A Historical Analysis; Ph.D Dissertation, University of Indiana, p.105. 
Jegede, D. (1987): "Synthesized Mannerism in Onobrakpeya's Art" Nigeria Magazine, Vol. 53, No. 3, JulySeptember.

Kasfir, S. L. (1999): Contemporary African Art; London: Thames and Hudson Ltd.

Kennedy, J. (1992): New Currents Ancients Rivers: Contemporary African Artists in a Generation of Change; Washington and London: Smithsonian Institution Press, p.75

Lawal, B. (1976): "The Mythical Realism of Bruce Onobrakpeya" Nigerian Magazine, No. 120, p.75

Lawrence, W. (1979): Bruce Onobrakpeya: Nigeria's Master Printmaker; Toronto: the Best of Africa, p.96.

National Geographic News (2012): World's Oldest Cave Art Found-Made by Neanderthals? http://news.nationalgeographic.com/news/2012/06/120614- neanderthal-cave-paintings- spain-sciencepike/ Retrieved on Wednesday, May 14, 2014

Nnadozie, U. (2006): "Printmaking in Nigerian Modern Art: an in-depth analysis of the art of Paul Igboanugo a master printmaker" Egghead: a Journal of Art, Zaria: Department of Fine Arts, Ahmadu Bello University.

Nzegwu, N. 1999: Contemporary Textures, Multidimensionality in Nigerian Art; Binghamton: International Society for the Study of Africa (ISSA).

Ojo, B., (2000): "Contemporary printmaking in Nigeria: An update", Journal of Creative Arts, Vol. 1, No. 2. Faculty of Arts, Port Harcourt: University of Port Harcourt.

Okeke-Agulu, C. (2012): "The Zaria Art School: From Wangboje to Okpe." Ezumeezu: Essays on Nigerian Art and Architecture. Glassboro, NJ: Goldline \& Jacobs, pp. 88-102.

Oladumiye, E. B. (2006): "Irein Wangboje: the Paragon of Printmaking Technique and the Creator of Ori-Olokun Experimental Workshop", in Aremu, P. S. O., Ademuleya, B. A., Sheba, E. A., Adejumo, E. A, and Ajiboye, O. J. (Eds.), Contemporary Issues in Nigerian Art: Its History and Education. Ile-Ife: Department of Fine Arts, Obafemi Awolowo University. Pp. 274-280.

Oloidi, O. (1993): "Modern Nigerian Art: Artistic Vitalization through varied Stylization", New Current '93 Avantgarde, Nigerian Art Exhibition Catalogue pp. 32-33.

Onakufe, S. (1999): "Plasto-Viscosity Print: Means and Method" in Bruce Onobrakpeya, Agbarha-Otor '98 and '99, 1st and 2nd Harmattan Workshop Exhibition Catalogue. Lagos: Ovuomaroro Studio and Gallery. Pp. 41-44.

Onobrakpeya, B. (1985): Bruce Onobrakpeya: Symbols of Ancestral Groves, Ikeja, Lagos: Ovuomaroro Gallery.

Onobrakpeya, B. (1999a): Forty years of Bruce Onobrakpeya in contemporary visual art. Lagos: Ovuomaroro Gallery.

Onobrakpeya, B. (1999b): "The Origin of Harmattan Workshop" in Mudiare Onobrakpeya and Ekpo Udo Udoma (Eds.) Agbarha-Otor '98 And '99: The 1st And 2nd Harmattan Workshop Exhibition. Lagos: Ovuomaroro Studio and Gallery, pp. 29-31.

Onobrakpeya, B. (2003): Bruce Onobrakpeya: Portfolio of Art and Literature. Lagos: Ovuomaroro Studio and Gallery.

Onobrakpeya, B. (2009): Jewels of Nomadic Images. Mushin, Lagos: Ovuomaroro Studio and Gallery.

Onyeanu, S. M. (2002): "Printmaking: an Aspect of Contemporary Nigerian Art History" in John Tokpabere Agberia (ed.) Design History in Nigeria. Port Harcourt: Department of Creative Arts.

Onobrakpeya, B. (2014): Onobrakpeya: Masks of the Flaming Arrows, edited by Dele Jegede. Milan: 5 Continents Editions.

Oyelola, P. (1976): "Everyman's Guide to Nigerian Art". Nigeria Magazine, Lagos: Department of Culture. P.106

Oyelola, P. (2003): "Signs of the Times: Introduction" in Bruce Onobrakpeya: Portfolio of Art and Literature, Pat Oyelola ed. Lagos: Ovuomaroro Studio and Gallery.

Oyelola, P. (2010): Nigerian Artistry. Ibadan: Mosuro Publishers.

Picton, J. (1997): Image and Form (prints, drawings and sculpture from Southern Africa and Nigeria); School of African and Oriental Studies (SOAS). London: University of London.

Picton, J. (2004): "On Marking and Masking in the Art of Bruce Onobrakpeya" in Perkin Foss (Ed.), Where Gods and Mortals Meet: Continuity and Renewal in Urhobo Art. New York: Museum of African Art, SnoeckDucaju \& Zoon, Gent; pp131-134.

Riley, S. A. (2012): Practical Mixed-Media Printmaking, A\&C Black Publishers.

Saff, D. and Sacilotto, D. (1978): Printmaking: History and Process. Orlando, Florida: Harcourt Brace Jovanovich, Incorporated.

Sheba, E. (2004): "Foreword" in Just Prints, catalogue of the first annual printmakers' exhibition, Ikoyi, Lagos; Mydrim Gallery, p.8.

Silvester, H. (2009): Natural Fashion: Tribal Decoration from Africa. London: Thames and Hudson Ltd.

Smithsonian National Museum of African Art (2014a): Conversations: African and African American Artworks in Dialogue from the Collections of the Smithsonian National Museum of African Art and Camille O. and William H. Cosby, Jr Kreamer, Christine Mullen and Adrienne L. Childs (eds.) Washington, D.C.: National Museum of African Art, Smithsonian Institution, p. 240, pl. 134.

Stijnman, A. C. J. (2012): A history of engraving and etching techniques: developments of manual intaglio printmaking processes, 1400-2000. Amsterdam: Archetype Publications. 
Urton, R. (2014): Printmaking: History and Techniques. http://www.robinurton.com/history/printmaking.htm Retrieved on Friday, January 31, 2014.

Visona, M. B., Poynor, R., Cole H. M. and Harris, M. D. (2001): A History of Art in Africa; New York: Harry N. Abrams, Inc., Publishers.

Walker, G. A. (2010): The Woodcut Artist's Handbook: Techniques and Tools for Relief Printmaking; Richmond Hill, Ontario, Canada: Firefly Books.

Willet, F. (2002): African Art: an introduction, (Revised Edition). New York: Thames and Hudson, p.106.

Woods, G. (1965): The Craft of Etching and Lithography, Holborn, London: Blandford Press Limited. 